\title{
Constructing Meaningful Lives: Biographical Methods in Research on Migrant Women
}

\author{
by Umut Erel \\ The Open University \\ Sociological Research Online, Volume 12, Issue 4, \\ < http://wnw.socresonline.org.uk/12/4/5.htm/> \\ doi:10.5153/sro. 1573
}

Received: 13 Mar 2007 Accepted: 11 Jul 2007 Published: 31 Jul 2007

\begin{abstract}
The article argues that biographical methods are particularly suited to shift the methodological and theoretical premises of migration research to foreground the agency and subjectivity of migrant women. It is argued that structural and cultural readings can usefully be applied to the self-representations of migrant women. The context of migrant women's self-representations is explored through looking at the story-telling communities they develop and through the expert knowledges of institutions regulating migration. The dichotomisation of unique versus collective modes of life-stories is questioned. Applying the Foucauldian concept of subjugated knowledges, it is argued that migrant women's life-stories hold transformative potential for producing knowledges critical of gendered and ethnocised power relations that research should pay attention to.
\end{abstract}

\section{Keywords: Migration, Gender, Ethnicity, Life-Story, Methodology, Britain, Germany, Structural and Cultural Readings, Subjugated Knowledges}

\section{Introduction}

Which speaking, discoursing subjects - which subjects of experience and knowedge - do you want to 'diminish' when you say: 'I who conduct this discourse am conducting a scientific discourse, and I am a scientist'? (Foucault 1980: 85)

1.1 What is the relation between migrant women as 'subjects of experience' and the establishment of 'scientific discourse' about them? This article critically examines the potential of life story methods in illuminating this relationship. The life stories migrant women tell in research encounters are produced in concrete dialogic contexts where the researcher and the interviewee co-produce the text. Collective stories that are elaborated within group cultures of the family, peer group, work place, social or political groups (Passerini 1987, Personal Narrative Group 1991) as well as dominant knowledges about migrant women reproduced in public discourses form wider social and narrative contexts in which life stories are produced.

1.2 These dominant knowledges are often reified in institutional practices of migration regulation, indeed, the provision of services through institutions of the societies of residence is stratified according to migration status. This civic stratification (Morris 2005) results in a situation where at many points of access to service provision (e.g. schooling, health, employment, benefits) migrant women are incited to produce particular self presentations that respond to the agendas and questions of these institutions. This article is primarily a contribution to methodological debates however I will also touch on some theoretical and substantive issues on gender and migration as my main argument is to encourage researchers employing life story methods in migration research to be more attentive to the particular power relations in gendered and ethnocised migration regulation and Othering as well as to individual and collective resistance strategies against this. I begin by briefly outlining the parameters of the politics of representation in research on migrant women and the uses of biographical methods within this. Then I turn to discuss some central concerns in life story research, i.e. of 'giving voice' and constituting the self, turning to the particular challenges research on migrant women poses to assumptions of subject and form in biography. In the remainder of the article I discuss how structural and cultural readings of migrant women's life stories can help us to improve our understanding of gendered migration. I pay particular attention to methodological questions of how emergent story telling communities of migrant women as well as the expert knowledges of migration regulation affect life stories of migrant women and are echoed in the research process. I close 
by looking at the transformative potential of looking at the subjugated knowledges articulated in migrant women's life stories and raising questions about the tensions between resistance and surveillance articulated within their narratives.

\section{Contextualising biographical research on migrant women}

2.1 Research on post-war migration to Western Europe has long constructed the male migrant as the prototype. If women migrants were acknowledged, it was as dependants. Migrant women have been portrayed as victimised on the one hand by the global structures of inequality forcing them to migrate, and on the other hand as women within the particularly oppressive gender relations of their families and wider ethnic communities. Structural factors contributing to migrant women's particular positioning such as the gendered institutional regulation of migration have not always sufficiently been taken into account in the explanatory frameworks of migration research. In response to this, a critical literature has begun to explore how factors such as the lack of the right to work as legally dependent spouses, formal and informal discrimination in the labour market (cf. Erdem 2000), as well as in civil society (Akashe-Böhme 2000, Rodriguez 1999, Toksöz 1991) play an important role in shaping migrant women's incorporation into their new society of residence.

2.2 Thus, immigration legislation, recruitment contracts and intermediaries play a crucial enabling and constraining role. For women who enter under family reunification legislation, this severely constrains their possibilities to take up work in the first years. Those who enter as tourists, students, au pairs, undocumented or asylum seekers, also face restricted (or illegalised) access to the labour market, and social rights. Often these immigration statuses - at least initially - increase their gendered vulnerability (cf. Kofman et al 2000). Yet, these interventions have not always made and impact on debates on migration and gender. Reductively culturalist approaches continue to be influential, especially in public debates beyond academia. Such approaches foreground the role of family life and a 'culture of origin' in their analysis of migrant women's lives.

2.3 In the literature on migrant women in Germany, both in quantitative and qualitative terms, images of women of Turkish background came to represent migrant women: 'From the 1970s onwards, a clear tendency towards the orientalization of migrant women can be identified: the debate on "foreign women" (Ausländerinnen) became a debate on Turkish women' (Inowlocki and Lutz 2000: 307). The key themes structuring research on migrant women from Turkey for the last three decades have been that of 'the (uncivilized) stranger, the victim of patriarchal honour and being "twice rootless"' (ibid.). The modernitydifference hypothesis (Apitzsch 1996) constructed migrants as backward and in need of catching up with modernity in Europe. In particular migrant women, due to their important role in the family were seen as representing tradition and the more 'originary' type of the culture of origin. Migrant women's commitment to the family was therefore seen as 'a particular obstacle in the process of modernisation' (Aptizsch 1996). These approaches have often used a monolithic concept of culture that did not take the self representations of migrant women themselves into account. At times, this has fostered the reproduction of oppressive truths and social realities through the social policy approaches they inform: they fix migrant women as passive and within the private sphere, while ignoring their interventions into community building and both participating in established public spheres, as well as creating their own public spheres (cf. Akashe Bohme 2000).

2.4 This article is a contribution to a shift in the methodological and theoretical underpinnings of research that values the self-representations of migrant women. Life story methods offer an important opportunity to take migrant women's agency into account and can contribute to a more nuanced understanding of gender and migration. ${ }^{[1]}$ Indeed, these methods have been favoured by a number of authors for challenging existing knowledges on migrant women (e.g. Gultekin 2003, Gutierrez Rodriguez 1999, Inowlocki and Lutz 2000 , Karakasoglu-Aydin 2000, Lutz 1991, Otyakmaz 1995, Riesner 1990). These contributions have demonstrated the usefulness of biographical methods for challenging (at times tacit) assumptions of research on migration, including:

- The position of migrant women can mainly be explained with recourse to their 'culture of origin'

- Migrant women have a 'deficit' (of modernity/ emancipation/ democratic values)

- Migrant women are recipients of (benefits, social services, education, etc.) rather than contributors (of paid and unpaid labour, cultural, political and social activities) to their societies of residence

- Migrant women are primarily victimised through the patriarchal values of their ethnic communities

- The society of residence offers migrant women an unproblematic avenue to emancipation through the adoption of the ethnically majoritarian gender norms, taken to embody democratic values.

2.5 One important aspect of this has been an epistemological shift that views migrant women's knowledges on self and the society they live in as central. This is a shift away from policy-driven approaches where the production of data that can feed into the production of state and/ or institutional policy and action was 
privileged.

\section{Constructing Meaningful Lives}

3.1 Despite all disciplinary differences in the use of life story methods there have been some shared assumptions about life story methods. ${ }^{[2]}$ The first is that of authenticity and giving a voice to marginalised views and voices. This has been an important emancipatory step in recognising that history and society are also lived and constructed 'from below', not entirely autonomous from official sources and records, but in dialogue with them. Yet, the underlying notions of authenticity and 'giving a voice' have been criticised from different vantage points. One of the criticisms is that the power relation between researcher and researched involves a setting of the agenda by the researcher, most importantly in the process of analysing and interpreting (cf. Gluck \& Patai 1991) as well as presenting (Lejeune 1980) the life story.

3.2 Stanley (1992) has argued that the biographical method, is importantly a telling of auto/biographies (Stanley 1992). Writing auto/biography encompasses different moments of ambiguity. The first refers to the distinction between fact and fiction. Writing a life is always bound up with degrees of fictionalising: be it through the allusion to (or use of) different narrative genres into which the life story is moulded or through the slips of memory, the life 'as it was actually lived' changes in the re-telling. To turn a life into a life story, moreover, coherence has to be produced, aided by a retrospective sense of direction, development or progression. There is also a moment of fictionalising in selecting and interpreting the events. These 'fictional' moments however are inevitable and an irreducible feature of life stories, however pronounced the narrator(s)' desire to be true to factuality, since life itself is ambiguous and always bound up with our making sense of it. The second moment of ambiguity relates to whose self is being represented: Stanley (1992) concedes that the understanding of the subject is mediated through the researcher's own biographical experiences. So that the ' $l$ ' that speaks or writes is inflected by both, the researcher's and the subjects biographies. The field of life writing is thus broadened and Stanley suggests that the distinction between auto-biography, biography and fiction is more usefully viewed as a continuum. Life stories or life in itself comes to be an epistemological category with specific effects on the inter-subjectivity of the research (Stanley 1992, Erben 1993).

3.3 Life story methods elicit not only what happened, but also how people experienced events, and how they make sense of them. Thus, life stories are an important vantage point for exploring the links between subjectivity and social structures. Memory and narrative are used for constructing a liveable, meaningful life story, aiming for a narrative wholeness of the self, notwithstanding the fact that these biographies are revisable. In this sense, life stories are an important element in constructing personal identity and its relation to collective identities (cf. Antze and Lambek 1996, Giddens 1991, Plummer 2001) ${ }^{[3]}$. Although certainly, the process of telling the life and the self is an important way of constructing identity, there are constraints on the type of stories that can be told in specific contexts.

\section{Migrant Women as subjects: querying auto/biographical forms}

4.1 Life story methods raise complex epistemological and ontological questions. on the constitution of subjects as individual and collective, the role of self knowledge and presentation in the constitution of the 'Self' as well as the 'life'. I certainly cannot fully discuss them here, but would like to comment on some of the gendered and ethnocized aspects here.

4.2 The canonisation of the autobiographical genre projects its origins to practices of introspection and memory developed in the Christian confessional. The canonisation of 'great' biographies and elevation of some autobiographies into the status of seminal texts thus contains specific gendered, racialised and classed evaluations about the form and subject of biography (Marcus 1994). This is particularly significant in the context of Orientalist power/knowledge structures that deny the quality of introspection and rationality to those from so-called Muslim cultures, instead viewing them as over determined by 'Oriental fatalism' and therefore lacking true originality and agency (cf. Said 1978).

4.3 Tracing the development of philosophy and criticism of the autobiographical genre from the 19th century onwards, Marcus (1994) argues that in the 20th century, 'creative' persons' autobiographies have come to be seen as the ideal type of the genre: 'seminal' autobiographies therefore are seen to express uniqueness. Auto/biographies of marginalised people challenge the gender, class, ethnic and culturally specific assumptions of an ideal subject of auto/biography. While this importantly aims at democratising practices of auto/biography, often there is an underlying dichotomisation that views these new voices 'from below' (Plummer 2001: 90) a priori as 'collective stories' (ibid.). As Plummer argues,

more marginal voices (...) speak not just of themselves but of and for 'others' in the world. The autobiographies 'from below' hence work to create a different sense of autobiographical form, one where consciousness of self becomes more of a collective exploration than just a 
private one (ibid.)

4.4 As Plummer rightly points out, these new voices often self-consciously aim at articulating collective identities and experiences of marginalisation. However, there is a danger that this disregards the complexities of subjected people's experiences and their representation. ${ }^{[4]} \mid$ agree with the necessity of deconstructing de-socialised notions of 'individuality' as particular claims to hegemony of white, European, male, bourgeois subjectivity. However, I think that instead of de-constructing these dominant subject positions the dichotomisation of individuality and collectivity is often used to simplify the constitution of subjected subjectivities: Lewis argues that class and race have become the binary divide along which the notion of self-knowledge as individual or collective is organised, assuming 'white people having psyches while black people have community' (1996:25), however instead of dichotomising the notions of individuality and collectivity they should be seen as aspects worth exploring in every life story. Thus, Portelli argues with regard to oral history that it is told 'from a multitude of points of view' that contain individual and collective standpoints, both of which can be seen as 'partial':

"Partiality" here stands both for "unfinishedness" and for "taking sides": oral history can never be told without taking sides, since the "sides" exist inside the telling. And, no matter what their personal histories and beliefs may be, historians and "sources" are hardly ever on the same "side". The confrontation of their different partialities - confrontation as "conflict", and confrontation as "search for unity" - is one of the things which make oral history interesting.' (Portelli 1991:57-8)

In this sense, dichotomizations of individual versus collective modes of biography do not take account of the complexity of life stories, both those told with an individual or collective inflection.

4.5 In the following I elaborate some of these issues as they can help shed a critical light on our understanding of migrant women. I discuss how the method relates to oral group cultures, story telling and interpretive communities and the production of expert knowledges. I then turn to examine how life stories, as situated, subjugated knowledges, can help develop more nuanced understandings of migrant women.

\section{Structural Readings}

5.1 Life stories can be read in various ways. They may be used to provide factual data on events that are not or only partially recorded otherwise. They also provide data on the impact of social structures on people, which is not obvious from looking at structural data itself. These ways of reading life stories have been termed by the Popular Memory Group (1982) 'structural readings'. [5] Those aspects of a life story that pertain to the ways in which meaning is constructed, they term 'cultural readings'. A cultural reading focuses on the way the interviewees give meaning to their experiences. These two aspects mutually constitute each other.

5.2 There are a number of useful structural readings of migrants' life stories: For example, the life stories reveal effects of immigration legislation on personal lives, which one cannot simply read off the legal or policy texts. They reveal structures of exclusion and resistance that quantitative or larger scale studies render invisible. Moreover they can call into question the categories of legislation and theorisation based on these as for example the discreteness of statuses of refugees, labour migrants, au pair, marriage migration, student migration, professional or undocumented migration. Some contemporary research still assumes that the migration into a Western country and the living conditions female migrants find there constitute their first encounter with modernity. It is assumed that European societies provide an entirely new avenue to emancipation. Instead, I would argue that migrant women are faced with multiple formations of modernity with contradicting effects of gendered control in both countries. The structures of incorporation into the receiving society may, at least initially, indeed enhance their gendered vulnerabilities. Since life stories do not narrow down lived experience to one single category or event, they offer a privileged vantage point for understanding and theorising the processual dynamics of migration and the intersectionality of gendered, ethnocised and class structures of power.

5.3 An example with respect to the effects of migration regimes, can clarify the uses of structural and cultural readings for understanding women's migration. Nilüfer ${ }^{[6]}$ entered England as an au pair, which was the only legal category allowing her entry. Her intention was to learn English and eventually join her father in Canada, when he fulfilled the residence requirements that would allow her to join him as his dependent daughter on the basis of family reunification. Soon after arriving in England however, she quit the au pair job because she felt she was treated 'like a slave'. Technically, she had become an illegal resident. However, she managed to get an au pair contract from a friend to maintain legal residence. In spite of this legal residence, she did not have the right to take up other employment. She found an undocumented job as a waitress, which did not however financially allow her to realise her aspirations of higher education because 
of the excessive overseas student fees. Nor could she afford to pay the fees to attend vocational colleges and English language schools, which she perceived as an alternative route to education. The irregularity of her residence and work permit status as well as the lack of social networks on whose financial, social and emotional support she could rely put her in a very vulnerable position. Despite this, she took the initiative to gain access to education: She entered a sexual relationship with her employer, who in turn paid her higher wages and guaranteed her employment:

$\mathrm{N}$ : But when I was working in that restaurant there, and I was very desperate as well. I had a relationship with the owner of the restaurant. He was thirty years older than me (laughs).

$\mathrm{U}$ : (laughing) Most of your boyfriends were much older, hah?

$\mathrm{N}$ : But this one was not boyfriend, this one was mostly- secure my job, secure my place and get more money. So this one was that. (...) Was terrible, it was disgusting.

$\mathrm{U}: \mathrm{Mhm}$, yeah.

$\mathrm{N}$ : It wasn't anything that I wanted to do because I love to do.

5.4 This extract shows how power relations of gender, class, and migration status rendered Nilüfer vulnerable to sexual and economic exploitation. However, this did not preclude her agency, and she used the limited resources to gain education which she hoped would enable her to 'get out' of this situation. In fact she found the situation of sexual exploitation so unbearable that she quit this job, lost her income and access to education. At another waitressing job, she worked for some months without getting paid. Her illegal residence and the undocumented nature of the work made it impossible for her to take any legal steps to receive her wages. At her workplace, Nilüfer met her husband, a man with regular residence status in Britain. Her husband's suspicion that she had married him mainly to obtain a secure residence status was a strain on their relationship. When her husband turned violent the considerations of leaving him or getting divorced for Nilüfer also included the fact that she had not yet got an independent right of residence. In spite of these structural constraints Nilüfer entered higher education and separated from her husband. At the time of interview, she was finishing her degree. Already this brief reading of Nilüfer's life story gives us factual information on the factors impacting on migrant women's life chances and choices. Moreover, it shows ways in which structural positioning constrained and channelled her agency but did not totally preclude it. In fact, Nilüfer's life story reveals counter structures to those of immigration control. These structures of undocumented residence arrangements and employment within an ethnic community are highly contradictory: while circumventing the restrictions of the British migration regime, they exploit other power relations such as gender and class.

5.5 As Lutz and Koser (1998) point out: 'Further investigations also need to take into account the development of new hierarchies outside and within settled immigrant communities.' (Lutz and Koser 1998: 14)

5.6 A dominant paradigm in the research on migrant women to Europe has viewed them as passive victims of processes of dislocation and modernisation. They have been seen as victimised at once through the process of migration and through the particularly strict patriarchal control by the men of their ethnic group. Life story methods that take the subjectivity of the interviewees as their starting point have a powerful potential to redress such representations since 'biography provides the link between the migrant agent and the structure of society.' (Lutz 1995: 314):

\section{Cultural Readings}

6.1 Nowadays, the life story has proliferated within media and has become a major mode of transmission of information of all kinds on a large scale. Be it in the fields of politics, publicity, literature or sport, 'as soon as one switches the button [of the tv or radio] one baths in the intimate, the direct, from man to man (sic!)' (Lejeune 1980:316, my translation from French). This public proliferation of life stories calls into question the assumptions primarily of classic literary biographies and autobiographies representing an authentic ' $l$ ' in the mode of sincere and painful confessional which can only find truthful expression as the outcome of introspection and reflection (cf. Marcus 1994).

6.2 Plummer (1995) has pointed out the relation of wider cultural and social conventions of story telling, experience and collective identities and the role of a public or audience. He argues that at the beginning of the gay and lesbian movement, coming out stories were crucial in building a collective identity of the social movement. By telling a coming out story, one addressed a gay and lesbian audience, and became part of this 'story telling community' (Plummer 1995). The audience was not just important in making formerly tabooised experiences speakable, as the speaker found a forum where their experiences were listened to. At the same time, the audiences took an active part in the elaboration of the stories by sympathising with or echoing some experiences, thus these story telling communities also created certain scripts for 'selfstories' (Denzin 1989) of what it meant to be gay. These self-stories were enabling and inclusive as they aimed at creating a community for gays and lesbians. On the other hand, these scripts also set limits and 
rules e.g. on the unspeakability of continuing heterosexual desire or relationships (cf. Stein 1997), or on how ethnic minority gay and lesbian identities could be (mis-)recognised and consequently became themselves disciplining and normalising.

6.3 In the interviews with migrant women from Turkey I have found that some stories were told, discussed and re-told and contributed to the establishment of collective identities. These stories differed in Germany and Britain, as the social conditions, history and modes of incorporation of migrants from Turkey differed. In the following I will focus on examples from the interviews in Germany. This took place on a large scale in the constitution of a social movement of migrants based on the political identity position of 'migrant'. In the late 1980s and early 1990s, a migrants' movement developed in Germany, which elaborated a political identity of 'migrant' as the privileged subject of anti-racist and anti-nationalist politics. This movement and identity developed in opposition to the dominant notion of 'foreigner' ('Ausländer') which was embedded in discourses which posited them as culturally incompetent strangers to German society, who could only be seen as either problems for or victims of German society. The migrants' movement elaborated a subject position in which 'migrant' came to signify a politically resistant identity against nationalist and racist discourses. As such it afforded a degree of autonomous political agency that the subject position of 'Ausländer' did not. Many of my second generation interviewees posited themselves in this discourse in their life stories (cf. Erel 2003).

6.4 One story that played an important part in the identity constructions of second generation migrant women was that of leaving the parental home. For most of my interviewees their leaving home took place against the wishes of their parents, in some cases the parents put up massive resistance to the young women's project of leaving home. Leaving home to live independently from parents or husband was ethnocized as 'leaving Turkishness' and parents tried to sanction their daughters' behaviour with threats of exclusion from the family and/ or wider ethnic community. Nilgün recalls that her mother threatened her and her younger sister:

'(...) if you go away l'll tell everybody that you are prostitutes, you know. And we said, "yes, do so." We were hurt, you know, but that wouldn't have prevented us anymore, it was simply too late, you know.'

6.5 For most of the young women this was a very emotional experience where feelings of loyalty towards their parents were negotiated. On the other hand, this was a conflict around different ethnocised gender identities. The parents (and others) threatened to sanction the young women's behaviour with the 'whore stigma' (Pheterson 1990) if they chose to live independently without marrying. At the same time, German friends, teachers, social workers and other migrants pressurised them into choosing one of two dichotomised ethnocised gender identities and making clear decisions about their loyalty and belonging: the young migrant women felt they had to choose between a 'German' and a 'Turkish' female lifestyle. Most young women had to deal with this traumatic process of leaving the parental home on their own, as Suzan recounts:

Suzan: '(...) earlier for me it was either you're a Turkish [female], then you've got to get married, you've got to do what your parents say, you've got to stay respectable, blablabla. Or, you are thus like virgin - whore, but in this case like Turkish -German. You're German, you've got a boyfriend, you can [have a] profession, blablabla. It was all extremes, it was divided, either-or, there was no being in-between. (...) in order to be with Germans, you had to reject everything that was Turkish absolutely, there was no way of keeping anything. (...) And I could not imagine having Turkish friends, I did not know any others who were like me.

U: Yes.

S: And for me it was (...) I ran away from home when I was 18 , didn't have any contact with my parents, didn't speak any Turkish- I nearly forgot all my Turkish and didn't want anything to do with it. And I moved out - ran away with the idea (...) that my parents would reject me. I never thought that instead they would lament me. [I thought, UE] that my leaving home would mean giving up my Turkish identity, giving it up completely.

6.6 Thus when later in their life they met other young women who had made similar experiences or who did not reject the gender roles they embodied, this became a turning point in their life stories.

Suzan: [When a male German friend told her about his female Turkish flat mate and her friends], you would really like them, they are like you' I was like ,I don't think so.' I was so certain that they'd be totally different. When I went to see him [the Turkish flat mate] wasn't there (....) but her dissertation [about second generation migrant women, U.E.] was lying around. My friend had done a drawing for her so I started leafing through it and when I started 
reading I could not believe it. This was my story and it was a hundred percent. I sat there and cried because for the first time I found ourselves in this - oh my god, oh my god oh my god, you know that was incredible, this feeling of being torn between the family and the boyfriend, having to adjust to both sides. It was incredible, a wonderful experience. (...) [When she met other women in this group] well for the first time I [realized] you can be Turkish and leave home and still do belly dancing, despite this you can still joke around in Turkish or in German if you feel like it, and yet none of them is a virgin! Oh that was so cool, for the first time I had found women who were like me - yet the fantastic thing about the group was that each one was different.

6.7 They talked about their different experiences of 'running away' ${ }^{\text {'7] }}$ and in these discussions elaborated a new identity for themselves that refused both 'German' and 'Turkish' hegemonic gender regulations. They could only begin to articulate these identities when an audience of young migrant women developed who were open for this and offered its support by listening. Of course, it is important to note that the space for a feminist migrants' audience was partly and importantly constituted through the emergence of political movements and the social spaces they initiated. In this sense the young migrant women played an important role for each other by collectively constructing new meanings and identities - by rejecting the ascriptions as 'whore' or 'Germanised' from parts of the 'Turkish' communities, or the ascription of being 'insufficiently emancipated' by their German environment, they articulated identities as (feminist) migrant women who claimed the authority to articulate their own ethnic identities without having to adhere to the rules of guardians of their reputation on the one hand or those wishing to 'liberate' them on the other. In this sense, the 'running away from home' stories played an important role in constructing alternative and oppositional repertoires of identity.

6.8 The telling of life stories is a truly social process in which those who coax the story tellers and listen to and interpret their story all take part (Plummer 2000). With the different roles, positions and intentions of the audience the meanings of a story change, too. A story about 'running away from home' takes on different meanings, according to whether it is told to a feminist migrants group, a social worker or a large chat show audience. Thus, when Suzan first left her parental home she was still a school student and in order to support herself she applied for income support. She needed to justify to a judicial officer that her relationship with her parents was putting unacceptable strain on her, otherwise she would not be deemed eligible for financial support but would be expected to move back in with her parents:

Suzan: (...) we had to go to the judicial officer about whether I was going to get income support or not and I had to testify against my parents, in the same room with them. That was really difficult.

U: Yes.

S: My boyfriend was sat next to me, for some reason I thought I cannot bear this situation on my own or even with another German girlfriend, I thought my boyfriend must needs be by my side. Today I would never do that, you know having my boyfriend sit next to me while facing my parents, uuuuugh (in a suffering tone, UE) that was so bad, anyway it was so bad. My mother cried all the time and my father...

U: Oh, I can imagine, how horrible!

S: And then there was this stupid German judicial officer who hasn't got a clue anyway and then there was this uh, ex-student - a friend of my parents who had in the meantime become a social worker and was a bit of a buffer between us. Oh my God, that was so bad, my goodness! But I had to do it - otherwise I wouldn't have gotten any income support. Well and one of the decisive factors why the judicial officer decided in my favour was when he saw my school reports. The reports from when I was living at home - my marks had deteriorated because I was suffering so much and also in the first period after leaving home. And the second term, after this my marks had improved at least three points in all subjects, in all of them.

U: Huhumm, huhumm.

S: And he was really impressed 'It seems this is doing you good.' And that was one of the things that clinched it, why I was allowed to live on my own. He decided it would not be acceptable to ask me to return to my parents. (...) And that is why I got income support.

6.9 Telling the story of leaving home to a judicial advisor had the purpose of proving she 'suffered' enough at home to warrant living apart from her parents. Yet, the audience she had in this situation consisting of 
German boyfriend, 'clueless' German judicial advisor, Turkish social worker as buffer and desperate parents all have different relations and expectations with regard to Suzan's story. Suzan alludes to the fact that already the spatial performance with her sitting next to her boyfriend, facing her parents and having to speak out against them in the presence of witnesses gave this re-telling a meaning of confrontation between her and her parents, that she would not have chosen herself. Moreover, it re-enacts the dichotomization of loyalties and re-instates the educational success as a means to and measure of distancing herself from both her parents and her emotional predicaments. ${ }^{[8]}$ Moreover having to tell her story so as to satisfy the adjudicator's criteria meant submitting to his interpretive frameworks. This contrasts sharply with the 'discovery' of commonality with the other young women of Turkish background. Rather than having to 'prove' her suffering, she could overcome it and claim a subject position that rejected ethnic dichotomizations of 'belly dancing' Turkish femininity on one hand and 'having a German boyfriend' on the other. ${ }^{[9]}$ These two contrasting examples demonstrate how life story methods shed light not only on the identities of the story teller but also on their relations with the audience they are addressing.

\section{Narrations of self between surveillance and resistance}

7.1 A crucial level of discourses enunciating migrating women are legislative: immigration, residence, employment, welfare, sometimes mediated by social work or community service agencies. These expert knowledges often mis-recognise and mis-represent the women's subjectivities, but in any case have discursive and material effects on the women's enunciation (for an excellent discussion of this cf. Gutierrez 1999). It is crucial to recognise that these expert knowledges form a powerful intertext in dialogue with which the women's own stories are told. Moreover, these expert knowledges themselves elicit self stories, whose function is often to survey and control the women's legitimity. Thus, Nilüfer pointed out to me that the research interview situation reminded her of her interview at the Canadian Embassy, when applying for family reunification with her father:

$\mathrm{N}:(\ldots)$ it's too much bureaucracy in the Canadian embassy- so by the time they decided that I can emigrate there - they had my life story as well there, and the woman said 'write a book' (laughs). I said 'what am I gonna do, I'm waiting'. She said 'write a book' (laughs) (p.22)

7.2 Giddens $^{[10]}(1991)$ argues that the generalisation of the telling of life stories as an everyday epistemology of the self is a response to 'ontological insecurity'. He points out the crucial functions of narrations of self in late modernity: on the one hand as personal strategies for making sense of life, striving to maintain a sense of 'ontological security' (1991:3) despite the general culture of risk, time-space compression and accelerating colonisation of life worlds. These personal projects of self reflexivity are however not one-dimensionally resistant de-colonisation's of the life-world, but deeply permeated with regulatory mechanisms. Techniques of self narration and identity formation are informed and elaborated through expert knowledges. Personal strategies of defence from abstract systems are not only individual projects, but are generated by and feed into collective life styles that form the basis of what Giddens terms 'life politics' that holistically engages persons in the negotiation of their life worlds with the abstract systems of late modernity. ${ }^{[11]}$

7.3 The telling of a life story, or a self story, is required of people in different contexts of regulation, normalisation and surveillance. For migrants, this practice often entails the implicit demand to justify why they are here, when they are going back, what the basis for their entitlements (e.g. to education, benefits, housing or jobs) or participation (in social, political, cultural practices and organisations) is. Thus, the kind of self-reflexive construction of self-identity that is required of them on an everyday basis does not centre on Giddens' assumed question of recuperating personal meaninglessness. Instead, the 'ontological insecurity' can indeed be heightened by the repetitive demand to legitimate their presence, their requests and their right to participate, as Sirin emphatically states, this can be felt as a disempowering intrusion transgressing a boundary of intimate self knowledge that is not voluntarily shared:

S: Well, I had a lot of difficulty for a while to, well you know to show some stupid stuff of mine. And you know l'm a visual artist in that sense I need to show something.

U: Huhumm, yes.

S: And I have always had such difficulty with this, because I never wanted to show anything of myself. I had such anxiety over making myself transparent. Because anyway - anyway you always wander through this world with your jumper pulled up. Because others always thought they had a right to question you about your parents. And uhm, everyone - you know every so often people look at your passport. How often do people look at the identity documents of Germans and how often do they look at your identity documents, at your birth certificate? How often do you have to repeat where you were born and why? And where your parents are, 
how much they earn, how often...? And that is - in front of what kind of people. Well it is, you have the feeling that constantly someone is pulling down your trousers and you're constantly trying to pull them back up again

7.4 Sirin presents the compulsion of having to tell and re-tell intimate details of her life story in order to justify her being in Germany as a voyeuristic, sexualized 'epistemological violence' (Spivak 1986). Against this backdrop she has found it very difficult to claim her own agenda in presenting herself through her artistic work. While issues of representation are important to Sirin for professional reasons, and she is the most eloquent in voicing these dilemmas, many interviewees raised the difficulties migrant women have in articulating their self-representations and being taken seriously, especially where their self representations challenge established knowledges on migrant women. Indeed, the surveillance of migrants already in the country has become a powerful tool of migration control so that the policing of external borders (that had been encapsulated in the metaphor of 'Fortress Europe') is complemented by the constitution of internal border zones. The streets, points of contact with social service provision or indeed the public transport system can become policed as 'border-zones' where those who are thought to be potential illegal migrants are subjected to spot checks (Embers 2001) and indeed people whose primary role is not that of border patrols, like school teachers, GPs and their receptionists, etc. are incited to survey the legitimity of migrants. This surveillance is based on rendering migrants transparent objects of knowledge, and Engbersen (2001) has suggested that the metaphor of 'Panopticon Europe' best captures this ${ }^{[12]}$. This enforced transparency differentially targets migrant populations according to 'race', ethnicity, class and gender; yet these techniques of surveillance of legitimity produce particular forms of subjection/ subjectification through the status of migrant.

7.5 In response to these forms of surveilling expert knowledges, another important intertext of expert knowledge for my interviewees were collective writings and theorisations of migrant women, to which they themselves contributed also. This should alert us that the boundary between 'expert knowledges' and selfreflexive constructions of self-identity is multi-directionally permeable and indeed the status of 'experts' can be challenged by fostering new forms of (self) knowledge production. This process was self consciously initiated by the migrants' and migrant women's movements referred to earlier and is ongoing. Pinar for example emphasises how she co-organized and spoke at local, national and international workshops and conferences of Black and migrant women as enabling her to make sense of and analyse her own position to articulate a claim for political and social participation as a migrant woman.

Pinar: In[M1] this context migrant women really struggled against the white structures here to say we do not want to be researched about anymore by white Germans. Instead we want migrant women to do research about us, you know. And we don't want to be seen as objects anymore on whose backs others create a name for themselves but we want to participate creatively and actively and we want to participate politically and legally and on every level. ${ }^{[13]}$

\section{Self-representations as subjugated knowledges}

8.1 Migrant women's knowledges can be described with Foucault as 'subjugated knowledges', that

have been disqualified as inadequate to their task or insufficiently elaborated: naïve knowledges, located low down on the hierarchy, beneath the required level of cognition or scientificity. (...) [these] disqualified knowledges (...) which involve what I would call a popular knowledge (le savoir des gens) though it is far from being a general commonsense knowledge, but it is on the contrary a particular, local, regional knowledge, a differential knowledge incapable of unanimity and which owes its force only to the harshness with which it is oppressed by everything surrounding it (...) (1980: 82)

8.2 Foucault argues that these subjugated knowledges can point beyond the limits of truth established by dominant discursive regimes, thus unfolding a transformative power. In this sense, migrant women's life stories can produce accounts of their selves alternative to or contesting the ways in which dominant discourses and practices (of citizenship, immigration legislation, public discourses of gendered ethnocisation as well as those of community-leadership) position them (cf. Mirza 1997).

\subsection{Let me give an example of how subjugated knowledges challenge dominant regimes of} representation ${ }^{[14]}$. The interviewees kept referring to stereotyping discourses on migrant women from Turkey, positioning their own experiences and their interpretation vis-à-vis these. Education was an important part of this stereotyping. Introducing herself and her family Birgül states:

B: My father is a farmer and my mother was a housewife. But my father was not a very rich farmer, he had a small property. Everyone in the family studied. All of us seven girls.

Everybody studied with their own efforts. All of them are graduates. I think maybe it was the 
influence of the older siblings that we studied, also.

\section{U: Have your parents supported you in that direction?}

B: Of course, this question always arises, as if in Turkey girls did not study. My mother and father were not against our studying, it was not a conservative family at all. They had beliefs, but they did not prevent our studying.

8.4 Birgül identifies my question about parental support of education in her family as casting her into the stereotype that assumes Turkish parents curtailing their daughters' education. By asserting her own experience as valid, she critiques these stereotypes, arguing in detail about the regional, local, religious, economic and gendered as well as idiosyncratic aspects affecting her education. She thus frames her explanation of 'who I really am' to address misrepresentation of Turkish femininity that deny the validity of her experiences and subjectivity.

8.5 This example relates to the extent to which subjugated knowledges can shed critical light on power relations. Thus, some interviewees used education as an identity marker to distinguish themselves from other migrant women. Such strategies of self representation may be useful in empowering them as individuals, to gain access to education, job networks, cultural recognition etc. but do not necessarily challenge other axes of oppression experienced collectively by other migrant women. Other interviewees explicitly challenged the use of education as a marker of intra-ethnic distinction. A narrative figure that I frequently encountered in the interviews was that of being 'an exception' among migrant women from Turkey. The uses and contestations of this narrative figure provided an example for how boundaries of individual vs. collective identities were ethnocized and classed. While being (seen as) exceptional in their German environment was at times and for some interviewees a source of pride, others were critical of this ascription. Deniz is one of my interview partners who was very critical of the ascription of being an exception on the basis of her educational achievements. She describes her changing attitude to this ascription when growing up in a small town where she was one of a very small number of migrant girls at her Gymnasium. ${ }^{[15]}$ She contrasts the overt racism she experienced in lower level schools where there was a higher proportion of migrants with the way she was treated at this school:

D: I have to admit that I sometimes felt that I was special, you know.

$\mathrm{U}$ : Yes, yes.

D: I was recognised and at the time I believed in it. Looking back at it, when I grew older I understood better how things worked. They used to say ,I don't mean you' when they were talking about migrants in my presence. When they spoke about what they disliked in migrants they mentioned on the side that they aren't talking about me, you know (...) I felt funny, what does this mean, that l'm supposed to be different. But I really only understood later what it meant.

8.6 Deniz describes being offered partial inclusion on condition that she dis-identify with the ,mass' of migrants and accept the ascription of being an ,exception'. The ascription of being an ,exceptional' migrant reinforces stereotypical representations of a mass of migrants. She refuses to accept an inclusion on the basis of a dis-identification with other migrants.

\section{Conclusion}

9.1 Life stories of migrant women are elicited and presented in various contexts: as stories to construct similarity and difference with other migrants, or to people of the majority ethnicity, to gain access to services and to justify their presence to different institutions, stories produced in research contexts, as well as stories told to oneself. This article has drawn attention to the context in which these life stories are told. While clearly life story methods offer a way to explore migrant women's self presentations, research on migrant women would benefit from exploring further the social and narrative context to these. Migrants are incited to tell their life stories, often involuntarily, in situations where they are expected to justify and legitimate their demands, entitlements and even their presence. This can be experienced as disempowering and make it difficult to lay claim to setting the agenda when telling one's life. This difficulty in narrating the self anticipates possible reactions and contestations of the validity of the meaning they give their experiences. During the interview, Sirin shared with me that she often wonders how a German woman would react to her views:

S: [my best friend and I, UE] we've noticed that we often imagine a phantom German woman who would sit here and censor us. 'What would she be thinking now?' we're always censoring ourselves, that's really strange.

$\mathrm{U}$ : Yes, (laughing) 
S: And just now I was thinking again what would she say if she were sitting here with us.

9.2 This reference to an internal dialogue with an imaginary 'phantom German' elucidates how narrative constructions of self in life stories complexly intertwine dominant and resistant discourses on 'who I am'. While life story methods offer a great tool for centering the self presentations of migrant women in research, it is important to remain alert to the ways in which these self presentations respond to and contain elements of dominant discourses. While some attention has been paid to the inter-subjective dimensions of eliciting life stories, this wider social context of enforced transparency of migrants is a factor shaping the data life story researchers produce and merits more critical attention. At the same time, the collective and individual strategies for subverting, contesting and hegemonizing their own alternative or opposition concepts of self also emerge within research encounters, be it as asides (e.g. Birgül's remark: 'as if girls didn't study in Turkey') or more explicitly thematising ascriptions of identities as exceptional or addressing politics of political, social and academic representation. In the period of research, late 1990s, two significant and contradictory contexts have been on the one hand the political articulation of 'migrants' movement and a feminist migrant and black women's movement on one hand and on the other the multiplication of migration control and surveillance as permeating many everyday activities of accessing services and claiming even banal rights for migrants.

9.3 As part of antiracist and feminist political and social projects, migrant women's life stories as 'subjugated knowledges' can point beyond the limits of dominant discursive regimes and become transformative, as the example of the empowering use of 'running away' stories showed. In this sense, migrant women's life stories can produce alternative and resistant stories that challenge the positions ascribed them structurally and discursively e.g. through citizenship practices or migration regulation. By telling their life-stories, not only in the research encounter but in other contexts, migrant women contribute to building (imagined) communities. Constructions of 'we' and 'l' are shifting in the life-stories, as are the collectivities they refer to. The shifting identity constructions of the interviewees both construct and question collective identities to varying degrees. I have pointed out that for migrant women the question of whether to emphasise individual or collective aspects of their identity is bound up with negotiating ethnocized identity ascriptions: claiming individualistic identity is often equated with partial inclusion into the ethnically dominant group while claiming a sense of collective identity is often presented as the consequence of a lack of individuality, understood as a particularly Western achievement. These are of course only 'unfinished' thoughts on the uses of life story methods in research on migrant women. The conditions of migration (and its regulation) are fast changing, new modes of control and surveillance will produce new forms of subjection/ subjectification that need to be contextualised. At the same time however new forms of oral group cultures will also develop their own styles of telling the self and transforming the limits of what was previously sayable.

\section{Notes}

1This is based on interview s I carried out in 1996 and 1999, eliciting life stories of 31 skilled and professional migrant w omen of Turkish background in Germany and Britain (Erel 1997; 2002).

2In the follow ing I use the terms life story method, and auto/biographical method interchangeably to denote this wide field of study and its varying aspects.

3ldentity here is understood as a dynamic process of becoming that negotiates ascriptions and social positioning, when referring to the 'self' I am referring more to the meanings elaborated by the interview ees rather than ascriptive aspects.

4Thus, w ith regard to Italian w orking class oral cultures Luisa Passerini argues that often people prefer employing stereotypical story telling personas to an introspective tone. How ever she cautions against confusing the choice of narrative style $w$ ith the life as it w as lived (1987).

5While my focus in this article is on cultural readings, I begin with a discussion of useful structural readings.

6 The interview s have been anonymised. The interview s w ere conducted in the languages the interview ees felt most comfortable w ith, i.e. English, German or Turkish. German and Turkish interview extracts have been translated by the author.

7 Meral is one interview ee who consciously chose the term, running aw ay from home' as she argues that it best expresses the urgency of her resistance against sexist control and repression she experienced at her parental home. For her, claiming this term as positive is an act of re-evaluating her identity that also expresses her pride in this achievement of independence. She does how ever acknow ledge that this is contested among other young w omen w ho may prefer to represent this part of their relationship $w$ ith their families in a less conflictual way.

8Realising their dreams of education has often been offset against experiencing sexuality in the life stories of the interview ees. Lutz (1993) points out that postponing sexual experiences $w$ as part of a bargain $w$ ith the women's families to enable them the spatial mobility to realise their educational $w$ ishes w hile maintaining a respectable identity. Discussing w omen's roles in Turkey 
more generally, feminists have pointed out that w omen's participation in different realms of the public sphere, e.g. professional life, political life has been conditional on their representation as de-sexualized beings.

9This show s how 'cultural' and 'structural' readings are mutually constitutive, as w ell as the ways in which individual meanings 'belly dancing' or 'joking around in German' resonate w ith w ider social meanings of ethnocized gendered femininities.

10While Giddens' (1991) argument is not about academic biographical methods, I read it as about the epistemological and ontological aspects of life story methods in everyday life. Contending that the difference betw een everyday and academic know ledges is one of degree rather than essence and that they mutually inform each other, I examine his arguments' implications for the use of academic biographical methods.

11I find some problems of Giddens' theory of self-reflexivity and the ensuing 'life politics' unresolved. The re-appropriation of meaning and identity from abstract systems may be a precondition for challenging class, gendered, racialised and other pow er relations. How ever, there is no necessary logic that will lead the empow ered subjects to engage in such politics. (Yuval-Davis 1994): 'Subjective feelings of empow erment and autonomy (...) cannot be the full criterion for evaluating the politics of a certain action.' (Yuval-Davis 1994: 186). I am not satisfied by Giddens' suggestion that self-reflexive narratives and 'life politics' recuperate a central problem of subjectivity in late modernity, 'personal meaninglessness' (Giddens 1991:9). Giddens' approach emphasises the adaptation of selves and subjects to disembedding circumstances. Instead, I w ould like to stress that these selves may proceed to challenge these disembedding circumstances. Though Giddens' model does not preclude such challenges, his emphasis on coherent self-identity suggests he displaces responsibility onto the self for reconciling in narrative, what is impossible to reconcile materially.

12Of course, internal and external modes of border controls are not mutually exclusive in practice.

13This statement raises many important issues $w$ ith relation to identity, politics and representation that I cannot fully address here, I have discussed the dimensions of participation and identity politics elsew here (Erel 2002a).

14How ever, as Foucault argues, subjugated know ledges are fragmented and dispersed and cannot a priori be assumed to be resistant: 'do they have any force in their fragmented form? Or do they risk to be incorporated into the discourses which disqualified them once they are disinterred?' (Foucault 1980: 86). Thus, auto/biographical disourses of migrant w omen can align themselves $w$ ith a variety of subordinated or dominant discourses and subject positions.

15In the German three-tiered secondary education system, this is selective school type prepares for university study, whereas Hauptschule and Realschule produce low er level qualifications that can give access to vocational training only. Migrants are over represented in the low er levels of the school system.

\section{References}

AKASHE-BÖHME, F. (2000) In geteilten Welten: Fremdheitserfahrungen zwischen Migration und Partizipation, Frankfurt a.M.: Brandes und Apsel.

ANTZE, P. AND LAMBEK, M. (1996) 'Introduction: Forecasting Memory', in Antze, Paul and Lambek, Michael (eds.) Tense Past, Cultural Essays in Trauma and Memory, pp. xi-xxxvii London: Routledge.

APITZSCH, U. (1996) 'Frauen in der Migration', in Frauen in der Einen Welt, no 1, pp. 9-25.

EREL, Umut (2002)

EREL, Umut (2002a)

EREL, Umut (2003)

DENZIN, N.K. (1989) Interpretive Biography. London: Sage

ENGBERSEN, G. (2001) 'The unanticipated consequences of panopticon Europe. Residence strategies of illegal immigrants', in V. Guiraudon and C. Joppke, Controlling a New Migration World , pp. 222-246

ERBEN, M. (1993) 'The problem of other lives: social perspectives on written biography' Sociology, 27, (1):15-25.

ERDEM, E. (2000), 'Mapping women's migration: A case study of the economic dimensions of female migration from Turkey to Germany' paper presented at the conference 'Assimilation - Diasporization Representation: Historical Perspectives on Immigrants and Host Societies in Post-war Europe' Second Workshop on Contemporary Migration History, Humboldt Universität Berlin, October 27-29.

FOUCAULT, M. (1980) Two Lectures. In: Power/Knowledge. Selected Interviews and Other Writings 197277. Hemel Hempstead: Harvester Wheatsheaf (pp. 78-108) 
GEDALOF, I. (2007) 'Unhomely Homes: Women, Family and Belonging in UK Discourses of Migration and Asylum', Journal of Ethnic and Migration Studies 33 (1): pp. 77-94.

GIDDENS, A. (1991) Modernity and self-Identity. Self and Society in the Late Modern Age. Cambridge: Polity Press.

GLUCK, S.B. AND PATAI, D. (eds.) (1991) Women's Words. The Feminist Practice of Oral History. London: Routledge.

GULTEKIN, N. (2003) Bildung, Autonomie, Tradition und Migration. Doppelperspektivität biographischer Prozesse junger Frauen aus der Türkei. Leske + Budrich, Opladen.

GUTIERREZ RODRIGUEZ, E.(1999) Intellektuelle Migrantinnen - Subjektivitäten im Zeitalter von Globalisierung. Eine postkoloniale dekonstruktive Analyse von Biographien im Spannungsverhältnis von Ethnisierung und Vergeschlechtlichung, Opladen: Leske und Budrich.

INOWLOCKI, L, AND LUTZ, H. (2000) 'The 'Biographical Work' of a Turkish Migrant Woman in Germany', in European Journal of Women's Studies vol 7 no 3, pp.301-20.

KARAKASOGLU-AYDIN, Y.(2000) Muslimische Religiösität und Erziehungsvorstellungen. Eine empirische Untersuchung zu Orientierungen bei türkischen Perham's- und Pädagogik-Studentinnen in Deutschland, Frankfurt: IKO Verlag für Interkulturelle Kommunikation

KOFMAN, E., PHIZACKLEA, A., RAGHURAM, P., SALES, R. (2000) Gender and International Migration in Europe. Employment, welfare and politics, London: Routledge.

LEJEUNE, P. (1980) Je est un autre. L'autobiographie de la litterature aux medias. Paris: Edition du Seuil.

LEWIS, G. (1996) 'Situated Voices. 'Black Women's Experience’ and Social Work', Feminist Review 53, pp. 24-56.

LUTZ, H. (1991) Welten verbinden. Türkische Sozialarbeiterinnen in den Niederlanden und in der Bundesrepublik Deutschland, Frankfurt: Verlag für interkulturelle Kommunikation.

LUTZ, H. (1995) 'The Legacy of Migration: Immigrant Mothers and Daughters and the Process of Intergenerational Transmission.' Commenius, (15),3, pp. 304-317

LUTZ, H. AND KOSER, K. (1998) 'The New Migration in Europe: Contexts, Constructions, and Realities', in Helma Lutz and Khalid Koser (eds.) The New Migration in Europe. Social Constructions and Social Realities, Houndmills: Macmillan. pp. 1-20.

MARCUS, L. (1994) Auto/biographical Discourses: Theory, Criticism, Practice. Manchester: Manchester University Press.

MIRZA, H. S. (1997) 'Introduction: Mapping a genealogy of Black British Feminism', in Heidi Safia Mizra (ed.) Black British Feminism. A Reader. London: Routledge, pp.1-30.

MORRIS, L. (2005) Control of Rights - the rights of workers and asylum seekers under managed migration IRP Discussion Pamphlet Series London: JCWI Publications OTYAKMAZ, B. Ö. (1995): Auf allen Stühlen. Das Selbstverständnis junger türkischer Migrantinnen in Deutschland. Köln: ISP Verlag.

PASSERINI, L. (1987) Fascism in Popular Memory: the cultural experience of the Turin working class , Cambridge: Cambridge University Press.

PERSONAL NARRATIVE GROUP (eds.) (1991) Interpreting Women's Lives: Feminist Theory and Personal Narrative. Bloomington: Indiana University Press

PHETERSON, G. (1990) Hurenstigma - Wie man aus Frauen Huren macht, Hamburg: Galgenberg.

PLUMMER, K. (1995) Telling Sexual Stories. London: Routledge.

PLUMMER, K. (2001) Documents of Life 2. An Invitation to a Critical Humanism. London: Sage.

POPULAR MEMORY GROUP (1982) 'Popular memory: theory, politics, method', in R. Johnson, G. McLennan, B. Schwarz, and D. Sutton (eds) Making Histories. Studies in history-writing and politics , London: Hutchinson. 
Albany: State University of New York.

RIESNER, S. (1990) Junge türkische Frauen der zweiten Generation in der Bundesrepublik Deutschland: eine Analyse von Lebensentwürfen anhand lebensgeschichtlich orientierter Interviews, Frankfurt/ M.: Verlag für Interkulturelle Kommunikation.

SAID, E. (1978) Orientalism. London: Routledge and Kegan Paul.

SPIVAK, G. C (1986) 'Three Women's Texts and a Critique of Imperialism’ in Gates, Henry Louis jr. (ed.) 'Race', Writing and Difference, Chicago: The University of Chicago Press, pp. 262-280.

STANLEY, L. (1992) The Auto/Biographical :; Theory and Practice of Feminist Auto/Biography. Manchester: Manchester University Press.

STEIN, A. (1997) Sex and sensibility. Stories of a lesbian generation, Berkeley, California: University of California Press.

TOKSÖZ, G. (1991) 'Ja, sie kämpfen - und sogar mehr als die Männer.'Immigrantinnen - Fabrikarbeit und gewerkschaftliche Interessenvertretung, Berlin: Verlag für Wissenschaft und Bildung.

YUVAL-DAVIS, N. (1994) 'Women, Ethnicity and Empowerment', Feminism and Psychology, 4,(1), pp.179198. 